\title{
Vegetation of the coastal fynbos and rocky headlands south of George, South Africa
}

\author{
D.B. HOARE*†, J.E. VICTOR**, R.A. LUBKE* and L. MUCINA ${ }^{\ddagger}$
}

Keywords: gradient analysis, numerical syntaxonomy, ordination, phytogeography, phytosociology

\section{ABSTRACT}

Community structure and composition of the coastal fynbos and rocky headland plant communities south of George southern Cape, were studied. Vegetation was analysed using standard sampling procedures of the floristic-sociological approach of Braun-Blanquet. The relevé data were subject to TWINSPAN-based divisive classification, and ordinated by Principal Coordinates Analysis with the aim to identify vegetation coenocline subsequently interpreted in terms of underlying environmental gradients. Most of the sampled vegetation was classified as coastal fynbos. The Leucadendron salignum-Tetraria cuspidata Fynbos Community was found to occupy sheltered habitats, whereas the Relhunia calycina-Passerina vulgaris Fynbos Community was found in exposed habitats. The other two communities characterise strongly exposed rocky headlands. The Pterocelastrus tricuspidatus-Ruschia tenella Community is wind-sheared scrub, and the Guzania rigens-Limonium scabrum Rocky Headland Community is a loose-canopy, low-grown herbland, characterised by the occurrence of partly salt-tolerant and succulent herbs. The ordination of the fynbos communities revealed a horseshoe structure allowing a direct recognition of a coenocline spanning two fynbos communities along the Axis 1 interpreted in terms of exposure to wind and salt spray. A considerable amount of alien plant infestation was also present. This appears to be the largest threat to the continued existence of this coastal fynbos.

\section{INTRODUCTION}

Fynbos occurring in close vicinity of the coast has been studied in detail in many regions of South Africa (Boucher 1977; Van der Merwe 1979; Cowling 1984; Taylor 1985; Hellström 1990; Taylor \& Boucher 1993; Hoare 1994). There are, however, still many portions of the coastline, especially outside formal reserves, which remain only poorly known. Only $79 \mathrm{~km}$ of the central south coast falls into existing protected areas, namely the Goukamma Nature Reserve, the Robberg Nature Reserve and the Tsitsikamma Coastal National Park (Jarman 1986). The promulgation of the Agulhas National Park may alter these statistics (World Wide Fund for Nature 1999).

The area along the coast south of George, the present study area, is of interest because of its scenic beauty and its location in the centre of the popular Garden Route. Interest in coastal development for recreational purposes throughout the Garden Route is likely to impact on areas which have not yet been encroached upon. The extent of vegetation cover outside formally protected areas has been considerably transformed, and of the remaining natural areas large portions have been invaded by alien species. It was therefore suggested by Cape Nature Conservation (George) that a detailed study be undertaken along the coast south of George to provide information on the local vegetation and flora and possible importance of the study area for conservation (G. Hellström pers. comm.). This particular study features descriptions of the plant communities of habitats close to the coastline.

\footnotetext{
* Department of Botany, Rhodes University, 6140 Grahamstown. South Africa.

Present address: Agricultural Research Council. Range \& Forage Institute, Private Bag X05, 0039 Lynn East. Pretoria

** National Botanical Institute, Private Bag X101, 0001 Pretoria

$\$$ Department of Botany. University of Stellenbosch. Private Bag XI.

7602 Stellenbosch. South Africa

MS received: 1998-07-24
}

\section{STUDY AREA}

The study area extended from Rooiklip, SE of Pacaltsdorp, to Ghwanobaai, $3 \mathrm{~km}$ E of Glentana (Figure 1), and covered \pm 190 hectares. Glentana, and the area west of it, has been extensively developed and was therefore found unsuitable for the intended study. The fynbos vegetation in the study area has been classified as Asteraceous Fynbos by Cowling \& Holmes (1992) and it was broadly classified by Acocks (1988) as "cultivated land, plantations, dense alien communities and open sandy areas', a description which gives a clear indication of the transformed state of the vegetation. The vegetation of the coastline area is classified as Dune Thicket (Low \& Rebelo 1996), which forms a mosaic with Dune Fynbos (Low \& Rebelo 1996) in the region including the study area.

The coastline consists of steep coastal cliffs ranging in height from 50 to 70 metres, forming rocky headlands. The plenitude of alternating bays and headlands has resulted in microhabitats with varying degrees of exposure to the prevailing winds, salt spray and sun. Coastal soils vary markedly according to substrate, but are often calcareous and coarse-grained. Topography is the dominant factor affecting soil formation and the removal of the products of weathering may exceed their formation, especially on slopes. The coastal cliffs of the study area are Rooiklip Granite-Gneiss of the Kaaimans Group and are pre-Cape intrusive granite rocks (South African Committee for Stratigraphy 1980). These rocks are important because, upon weathering, they form base-rich substrates containing exchangeable cations that are important for soil formation and plant nutrient cycling (Deacon et al. 1992).

The Köppen's climate classification code for the George coastal area is $\mathrm{Cfb}$, which indicates warm, temperate climate (Schulze \& McGee 1978). The mean annual temperature is $\pm 17^{\circ} \mathrm{C}$, with a mean temperature range 


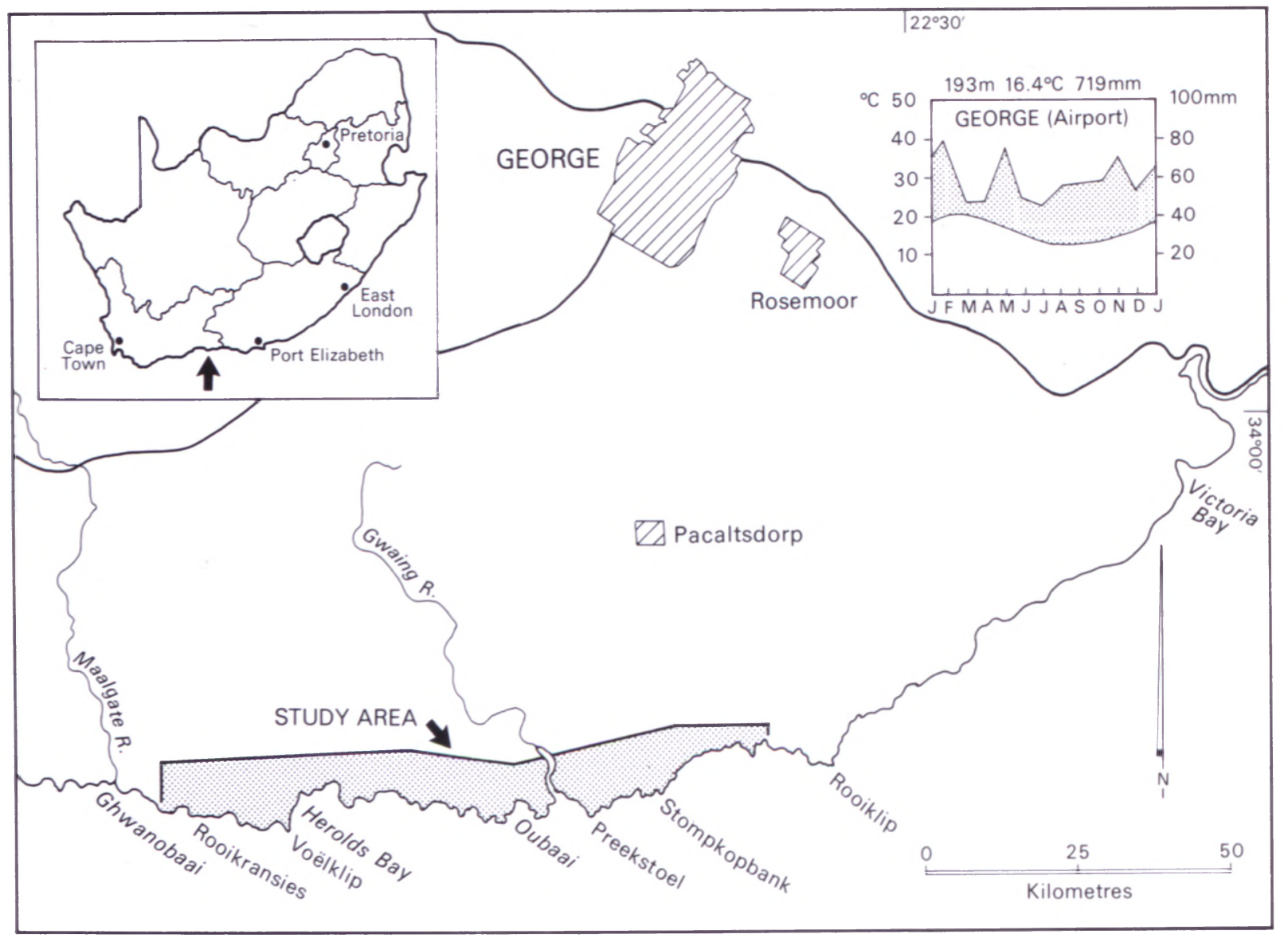

FIGURE 1.-Map of the study area and climate diagram for George.

of $8^{\circ} \mathrm{C}$ near the coast. The area has precipitation during all months of the year, with three prominent peaks in spring, summer and autumn, although there is no precipitation deficit at any time of the year (Figure 1). Sea mists may provide additional moisture on seaward-facing slopes. Pronounced strong winds blow along the entire coastal belt, varying in direction according to location and season. In the study area, wind from the southwest and west were found to be more important, since their frequency was higher (Weather Bureau 1994). Wind velocity has been found to be important in coastal plant communities, since the greater the velocity of the wind, the higher the salt load of the moving air, which may have a serious detrimental effect on the growth of plants (Avis \& Lubke 1985). Importance values (Table 1) were determined which took into account the velocity and frequency of winds from different directions (IV = mean monthly direction frequency multiplied by mean monthly velocity expressed as percentage of total of all values for year). Westerly winds had the highest importance values throughout the year but were of greatest importance during the winter months. Southwesterlies showed a similar pattern. Easterlies and southeasterlies had the second highest importance values, but these were most prevalent during spring and summer (September to March).

\section{MATERIAL AND METHODS}

Aerial photographs were used to stratify the region into broad vegetation complexes based on vegetation structure and relevés $\left(25 \mathrm{~m}^{2}\right.$ each) were made within these zones. The quadrat size was determined from species/area curves drawn from data collected in the study area, but also conformed to a scale-related approach to vegetation sampling, i.e. the size of the relevé was related to the scale at which the vegetation was studied (Rutherford \& Westfall 1994). Riparian thicket, dune thicket, dense alien stands and agricultural lands were not sampled. Standard field techniques and the 7-grade sampling scale of Braun-Blanquet (Westhoff \& Van der Maarel 1973; Werger 1974) were used to record the cover/abundance values for each vascular species encountered in the relevés. Topographic information, including slope, aspect and altitude were also

TABLE 1.-Importance values of winds from different directions in the months of the year. Bold text shows cells with importance values greater than I. (IV's calculated from data from Weather Bureau. See text for method)

\begin{tabular}{lllllllll}
\hline Month & N & NE & E & SE & S & SW & W & NW \\
\hline J & 0.01 & 0.07 & $\mathbf{2 . 6}$ & $\mathbf{2 . 3}$ & $\mathbf{1 . 7}$ & $\mathbf{1 . 8}$ & $\mathbf{1 . 1}$ & 0.3 \\
F & 0 & 0.1 & $\mathbf{2 . 8}$ & $\mathbf{1 . 8}$ & $\mathbf{1 . 6}$ & $\mathbf{1 . 4}$ & 1.0 & 0.4 \\
M & 0.03 & 0.04 & $\mathbf{1 . 7}$ & $\mathbf{1 . 6}$ & $\mathbf{1 . 2}$ & $\mathbf{1 . 1}$ & 1.0 & 0.3 \\
$\mathrm{~A}$ & 0.08 & 0.04 & 0.8 & 1.0 & 0.9 & 1.0 & $\mathbf{1 . 6}$ & 0.8 \\
M & 0.35 & 0.08 & 0.5 & 0.5 & 0.5 & 1.0 & $\mathbf{3 . 5}$ & $\mathbf{2 . 1}$ \\
J & 0.48 & 0.05 & 0.4 & 0.3 & 0.4 & 0.7 & $\mathbf{2 . 7}$ & $\mathbf{2 . 7}$ \\
J & 0.39 & 0.1 & 0.5 & 0.5 & 0.5 & 0.7 & $\mathbf{2 . 5}$ & $\mathbf{2 . 0}$ \\
A & 0.38 & 0.1 & 0.9 & 0.8 & 0.8 & 1.0 & $\mathbf{2 . 5}$ & $\mathbf{1 . 5}$ \\
S & 0.24 & 0.1 & $\mathbf{1 . 2}$ & $\mathbf{1 . 3}$ & 0.9 & $\mathbf{1 . 3}$ & $\mathbf{2 . 3}$ & 0.9 \\
O & 0.10 & 0.06 & $\mathbf{2 . 3}$ & $\mathbf{1 . 6}$ & $\mathbf{1 . 2}$ & $\mathbf{2 . 0}$ & $\mathbf{1 . 8}$ & 0.7 \\
N & 0.03 & 0.02 & $\mathbf{2 . 9}$ & $\mathbf{2 . 0}$ & $\mathbf{1 . 6}$ & $\mathbf{1 . 7}$ & $\mathbf{1 . 5}$ & 0.4 \\
D & 0.01 & 0.05 & $\mathbf{2 . 3}$ & $\mathbf{2 . 2}$ & $\mathbf{1 . 7}$ & $\mathbf{1 . 8}$ & $\mathbf{1 . 5}$ & 0.3 \\
TOTAL & 2.1 & 0.8 & 18.9 & 15.9 & 13.0 & 15.5 & 23.0 & 12.4 \\
\hline
\end{tabular}


recorded. Physical soil properties, such as $\mathrm{pH}$, conductivity, organic matter content, water-holding capacity, as well as the relative fraction of coarse, medium and fine sand, silt and clay, were ascertained in a subset of 20 relevés. The general methodology used by the US Department of Agriculture (USDA 1972) was followed for analysing soils.

The vegetation data were initially classified using TWINSPAN (Hill 1979), producing a rough species-byrelevé matrix, which was further rearranged in order to finely tune the relevé/species coincidence patterns supposed to carry meaningful ecological information. The data from only the fynbos communities were subject to ordination by Principal Coordinates Analysis based on similarity ratio as resemblance measure with no à priori data transformation using the programme package SYNTAX-5 (Podani 1993, 1994).

For the descriptions of vegetation communities, three informal ranks of vegetation units are recognised: community, subcommunity, and facies. Facies (BraunBlanquet 1964) represents the lowest-ranked unit and corresponds to vegetation stands dominated by a single species, mostly an alien element.

\section{RESULTS ANI) DISCUSSION}

\section{Classification of plant communities}

The rearranged species-quadrat matrix (Table 2) revealed two groups of plant communities: the majority of the relevés were classified as coastal fynbos (Communities A \& B) and the remainder of the relevés as (non-fynbos) rocky headland communities (Communities C \& D). A summary of the community environmental and floristic relationships is given in Figure 2. The following communities, subcommunities and facies were identified:

\section{A. Leucadendron salignum-Syncarpha paniculata Fyn- bos Community}

This community occurs in areas that are protected from coastal winds either by headlands or the proximity of coastal thicket (Figure 3) and has a different species composition to the fynbos on the exposed summit of the coastal cliffs. Diagnostic species: Leucadendron salignum. Aspalathus asparagoides, Hermannia angularis, Metalasia acuta, Helichrysum cymosum and Bohartia aphylla. Dominant species: Syncarpha paniculata and Passerina vulgaris. Common species: Tetraria cuspidata, Cliffortia falcata, Metalasia pungens, Lobelia tomentosa, Erica discolor and Phylica confusa. Many stands of this community have been seriously invaded by the alien species Acacia cyclops, Leptospermum laevigatum and Pinus spp.

Slopes vary from moderate to steep and soils are generally deeper and finer-grained than on cliff summits. There is high species richness ( 19 species on average) in this community. The habitat is more variable than on the cliff summits, thus leading to a greater species turnover between localities. The geographic distribution of this community beyond the present study area is unknown. Four subcommunities are recognised and described.

\section{Aa. Thamnochortus cinereus Subcommunity}

Diagnostic species: Thamnochortus cinereus, Polygala microlopha and Cliffortia sp. (Victor 313). It is situated below a housing development at Herold's Bay Extension; there was no evidence of recent fire and the subcommunity is possibly one form of a fire-climax vegetation in protected areas.

\section{Ab. Protea neriifolia Subcommunity}

Diagnostic species: Protea neriifolia. It has developed in the absence of fire and is possibly a fire-climax vegetation of protected areas. Bobartia aphylla and Pelargonium fruticosum serve as common linking species to subcommunites $\mathrm{Aa}$ and $\mathrm{Ab}$.

\section{Ac. Typical Subcommunity}

Lacks the diagnostic species of the other three subcommunities, but contains the diagnostic species of the Leucadendron salignum-Syncarpha paniculata Fynbos Community. There was evidence of recent fires in a number of the relevés.

\section{Ad. Hermannia althaeifolia Subcommunity}

Diagnostic species: Hermannia althaeifolia, Hibiscus aethiopicus, Ficinia albicans and Ursinia saxatilis as well as a number of infrequently occurring species (Table 2). Most of the relevés had evidence of being burnt recently, suggesting that it is an early post-fire successional stage.

The vegetation height varies from $1 \mathrm{~m}$, where dwarf shrubs are dominant, to over $2.5 \mathrm{~m}$ where shrubs of the exotic Leptospermum laevigatum are found. The mean species richness of this subcommunity is 20 species on average, but this may be reduced to only eight species where invasion by exotic shrubs has taken place, as is the case of the Acacia mearmsii facies (Table 2, rel. 23).

\section{B. Relhania calycina-Phylica confusa Fynbos Commu- nity}

This community makes up the greatest proportion of the fynbos in the study area and also extends beyond the boundaries of the present study area along the summit of the coastal cliffs towards Knysna (Figure 3). Diagnostic species: Relhania calycina subsp. calycina and Viscum capensis. Dominant species: Erica discolor, Phylica confusa. Passerina vulgaris and Tetraria cuspidata. Common species: Thesium virgatum. Agathosma ovata, Erica peltaia. Syncarpha paniculata and Clifforia serpyllifolia.

The dwarf shrub layer of this community is usually about $1 \mathrm{~m}$ in height and the herb layer about $0.4 \mathrm{~m}$. The total cover of the vegetation is slightly lower than for 
TABLE 2.-Classification of the vegetation of the coastal cliff habitats south of George, South Africa

Key to communities and subcommunities

A: Leucadendron salignum-Syncarpha paniculata Fynbos Community

Aa: Thamnochortus cinereus Subcommunity

Ab: Protea neriifolia Subcommunity

Ac: Typical Subcommunity

Ad: Hermannia althaeifolia Subcommunity

F: Acacia mearnsii facies

B: Relhania calycina-Phylica confusa Fynbos Community

Ba: Tetraria cuspidata Subcommunity

$\mathrm{Bb}$ : Eriocephalus africanus Subcommunity

C: Pterocelastrus tricuspidatus-Ruschia tenella Coastal Scrub Community

S: Sporobolus virginicus facies

D: Gazania rigens-Limonium scabrum Rocky Headland Community

$\mathrm{G}$ : Gazania rigens facies

Legend to vegetation layers: hl, herb layer; jl, juvenile woody species; s1, upper shrub layer; s2, low shrub layer; t3, low tree layer. Taxonomic notes, Gazania rigens = Gazania rigens var. uniflora; Limonium scabrum agg. is a new taxon pending formal description ( $\mathrm{L}$. Mucina, in prep.) and is closely related to $L$. scabrum (Thunb.) Kuntze; Drosanthemum marinum agg. is a complex of $D$. marinum and $D$. delicatulum and might represent one taxon after a revision (P. Burgoyne pers. comm.).

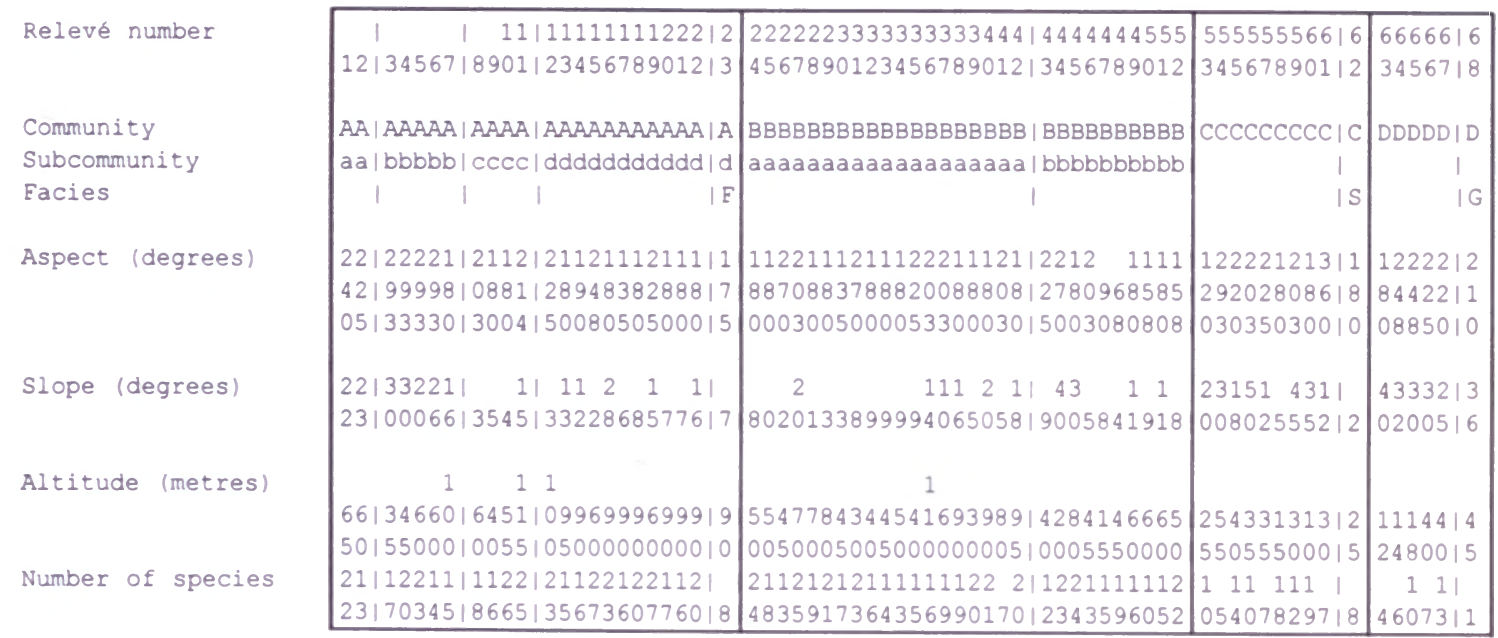

\section{Coastal Fynbos}

Tetraria cuspidata

Thesium virgatum

Syncarpha paniculata

Erica formosa

Cliffortia falcata

Metalasia pungens

Erica peltata

Schizaea pectinata

Restio triticeus

Lobelia tomentosa

Centella virgata

Pentaschistis eriostoma

Ficinia nigrescens

Carissa edulis

Aspalathus alopecurus

Anthospermum prostratum

Cullumia bisulca

Aspalathus florifera

Falkia repens

Crassula subulata

Disparago kraussii

Erica ericoides

Rhus lucida

Wahlenbergia desmantha
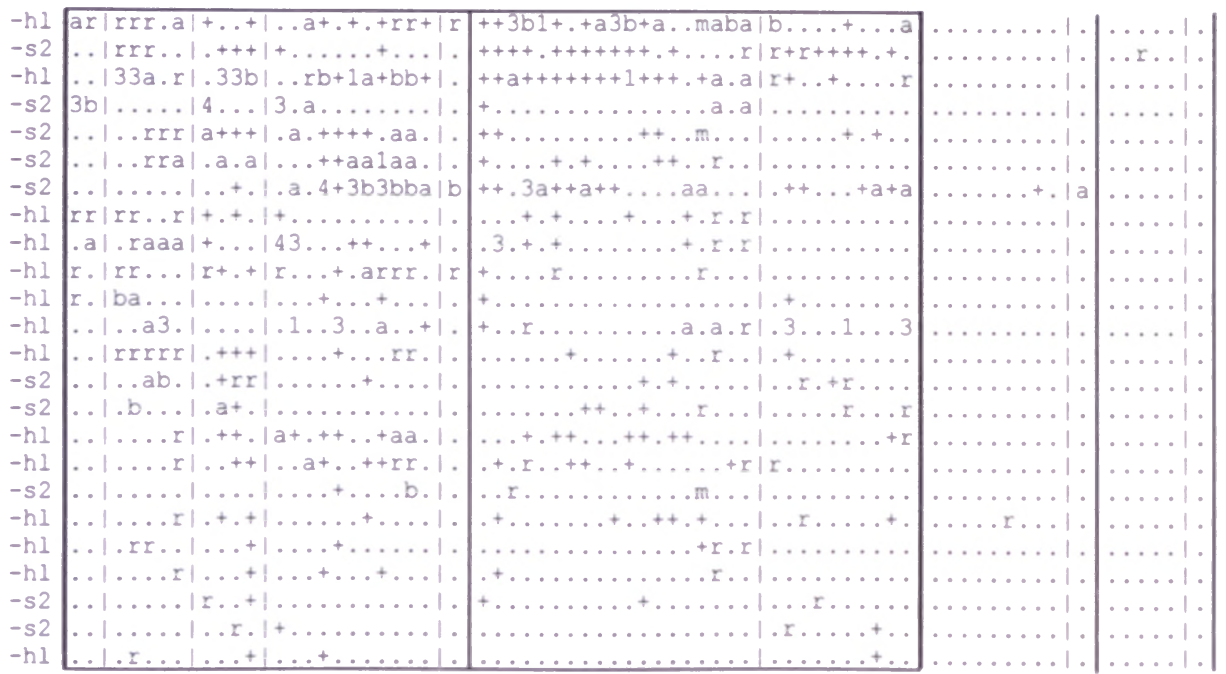

Leucadendron salignum-Syncarpha paniculata Fynbos Community

Leucadendron salignum

Aspalathus asparagoides

Hermannia angularis

Metalasia acuta

Helichrysum cymosum

Bobartia aphylla

Pelargonium fruticosum
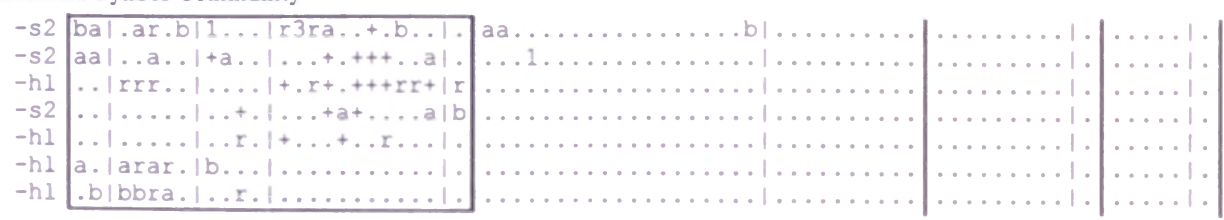
Thamnochortus cinereus Subcommunity

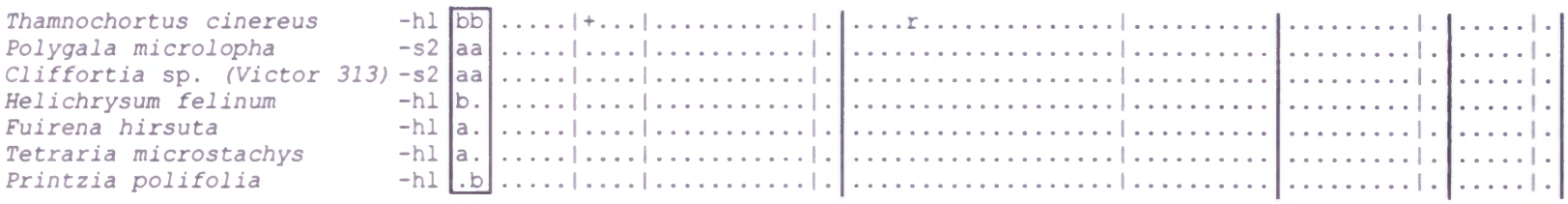

Protea neriifolia Subcommunity

Protea nerifolia

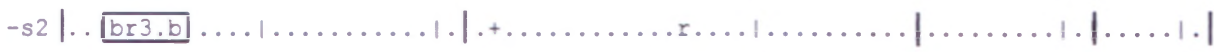

\section{Hermannia althaeifolia Subcommunity}

Hermannia al thaeifolia

Hibiscus aethiopicus

Ursinia saxatilis

Ficinia albicans

Clutia alaternoides

Relhania pungens

Chrysanthemoides monilifera

Diospyros lycioides

Aspalathus kougaensis

Tritoniopsis antholyza

Gerbera serrata

Ficinia quinquangularis

Ischyrolepis triflora

Themeda triandra

Acacia mearnsii facies

Acacia mearnsii

Leptospermum laevigatum
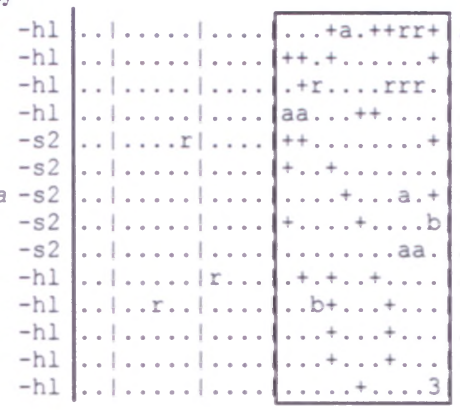

\begin{tabular}{l|l}
$-t 3$ & $\ldots$ \\
$-t 3$ & $\ldots$
\end{tabular}

Relhania calycina-Phylica confusa Fynbos Community

Relhania calycina
Viscum capense
Helichrysum teretifolium
Cassytha ciliolata
Carpobrotus edulis
Stoebe microphylla
Secamone alpini
Tetraria robusta
Tetraria compressa
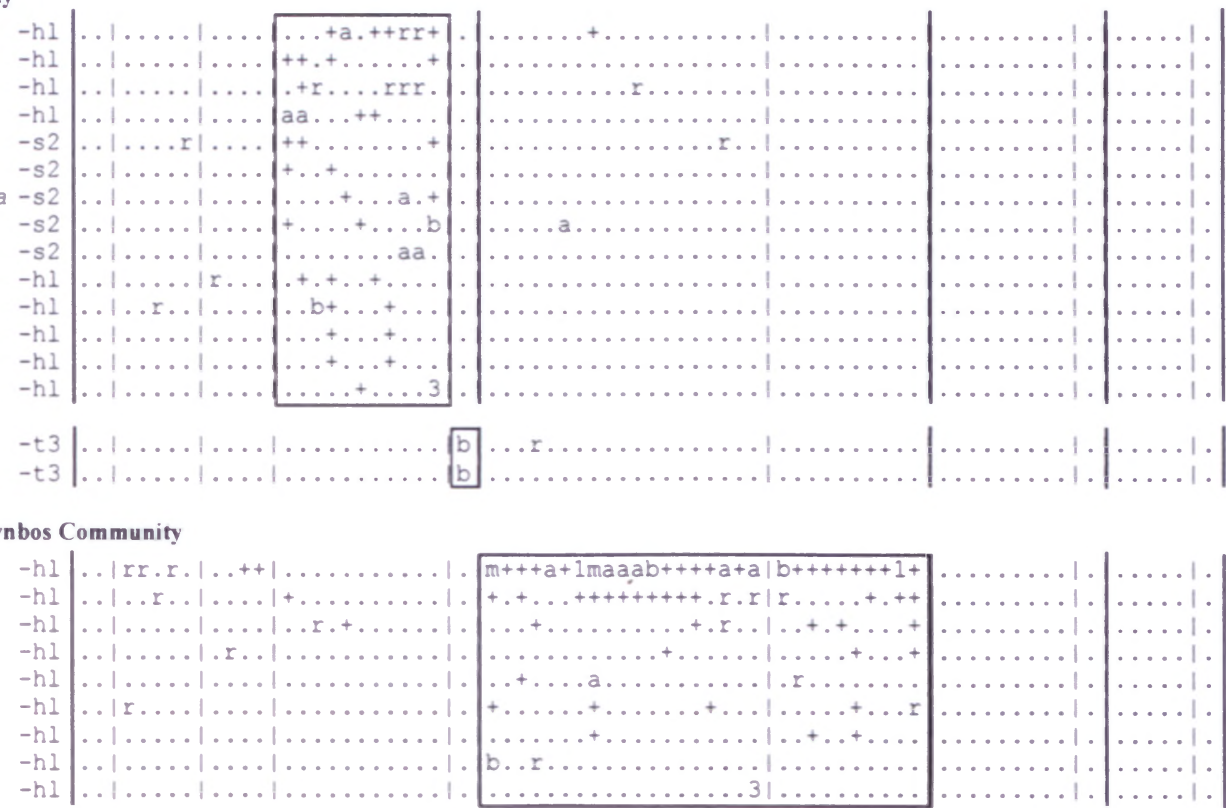

\section{Eriocephalus africanus Subcommunity}

Eriocephalus africanus

Ficinia repens

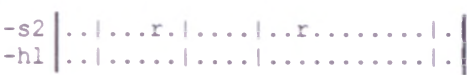

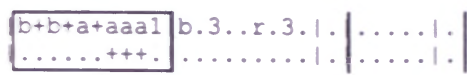

\section{Ruschia tenella-Gazania rigens Coastal Rocky Headland Community}

Ruschia tenella
Limonium scabrum agg.
Gazania rigens
Drosanthemum marinum agg.
Tetragonia decumbens
Sporobolus virginicus
Sarcocaulon natalense
Carpobrotus deliciosus
Thesidium fragile
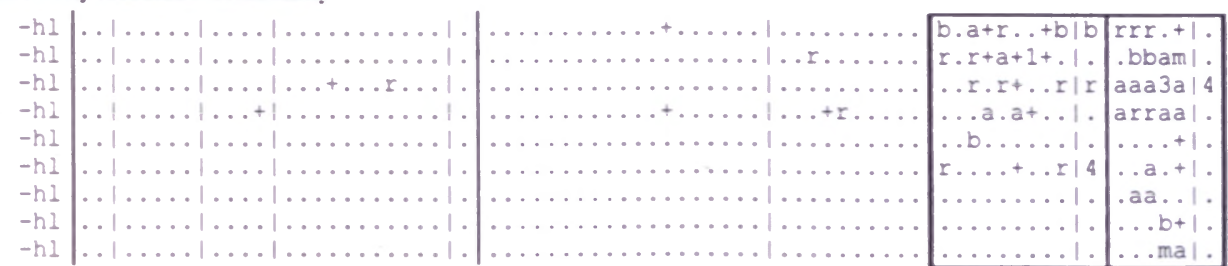

Pterocelastrus tricuspidatus-Ruschia tenella Coastal Scrub Community

Pterocelastrus tricuspidatus -s 2 ... . . r... r.r.| . .

Sideroxylon inerme

Delosperma edwardsiae

Cineraria britteniae
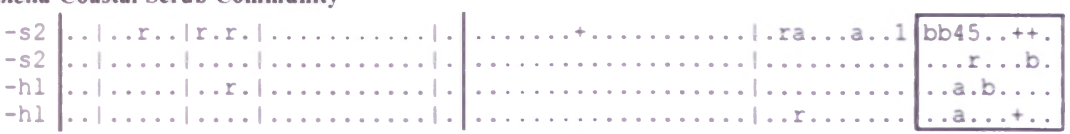

Other native spp. common to coastal fynbos and rocky headland habitats

Passerina vulgaris
Erica discolor
Phylica confusa
Cliffortia serpylifolia
Agathosma ovata
Colpoon compressum
Agathosma apiculata
Indigofera heterophylla
Lampranthus sociorum
Thesidium podocarpum
Chironia baccifera
Crassula sp.
Oxalis sp.

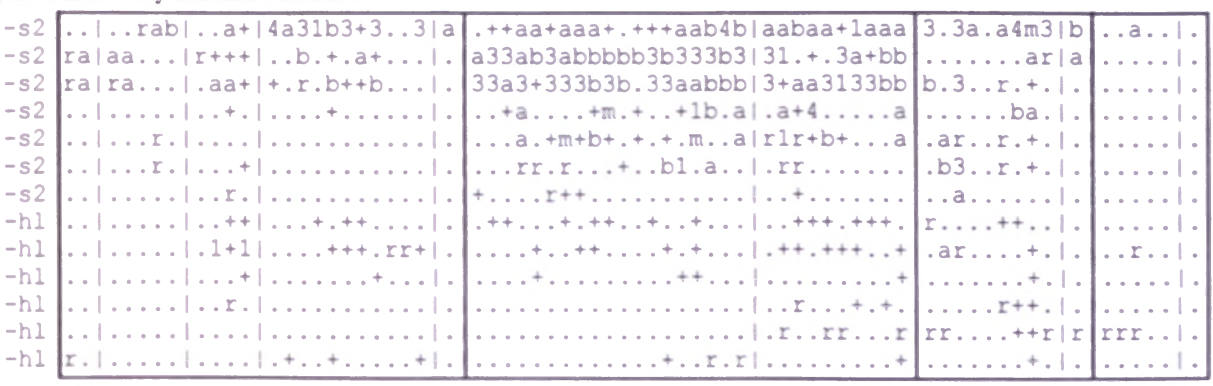

\section{Invasive alien spp.}

Acacia cyclops

Acacia cyclops

Pinus pinaster

Pinus pinaster

Leptospermum laevigatum

Casuarina sp.

Leptospermum laevigatum

Acacia mearnsif

Hakea sericea
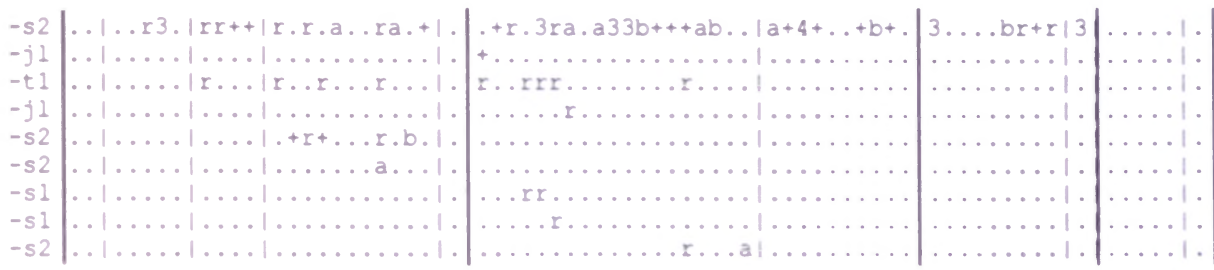
TABLE 2.-Classification of the vegetation of the coastal cliff habitats south of George, South Africa (cont)

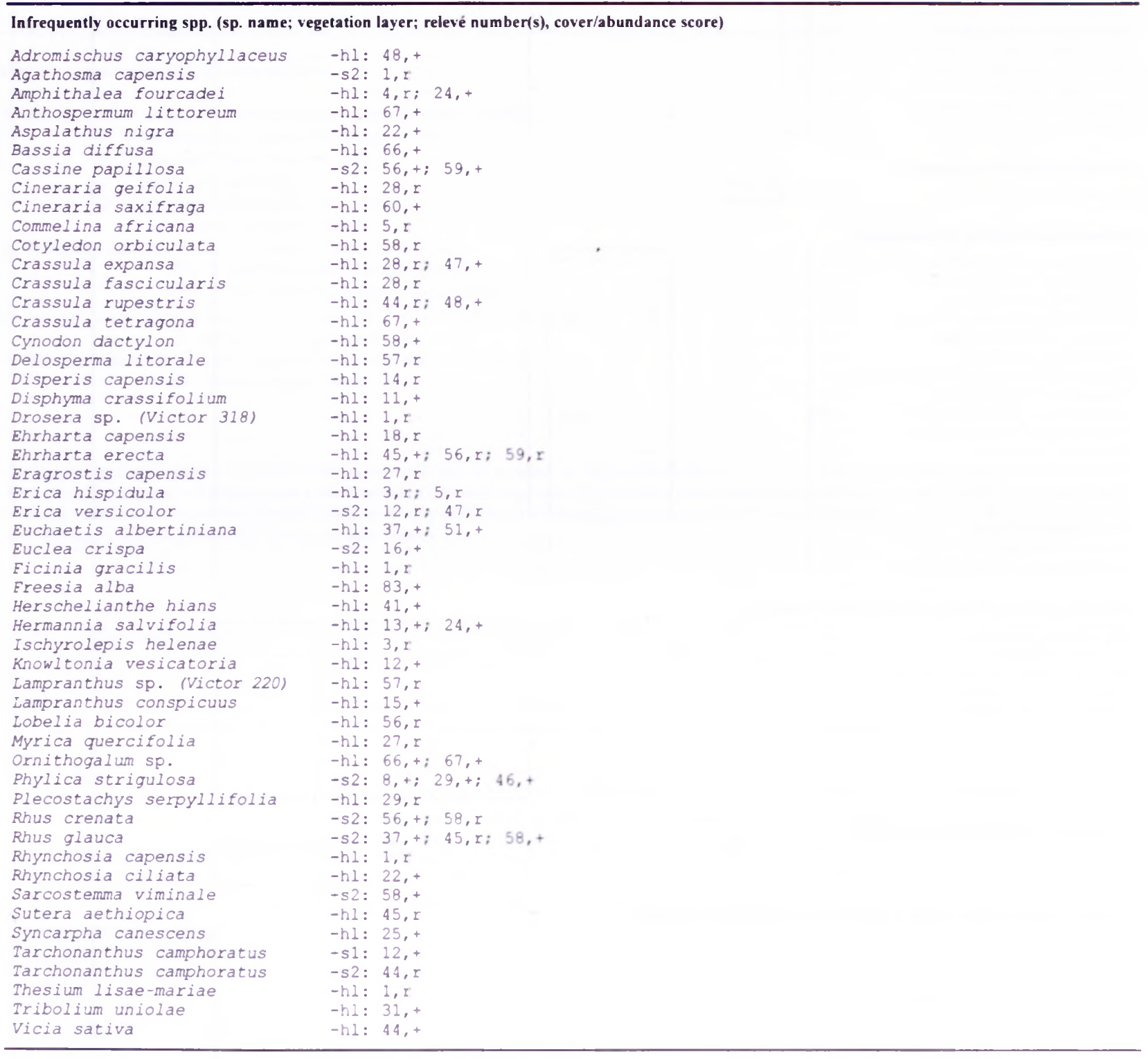

other fynbos communities in the study area, mostly due to an absence of a distinct restioid stratum. The community is exposed to sun and wind and is consequently hot and dry. Compounding this dryness, the soils are generally shallow and stony due to natural surface erosion at the summit of these cliffs. Slopes vary from flat to moderate. The community tends to grade into thicket inland, often with a tall Passerina belt before the true thicket. There is a high degree of invasion by Acacia cyclops (present in $78 \%$ of relevés), possibly causing habitat modification, which could ultimately lead to irreversible changes in species composition and vegetation structure.

\section{Ba. Tetraria cuspidata Subcommunity}

This subcommunity has the same dominant and common species as the Community itself, but with Viscum capense as a common species. It is usually found more inland of the other subcommunity suggesting that the two subcommunities form a gradient from lower altitude to wind-protected inland plant communitics.

\section{Bb. Eriocephalus africanus Subcommunity}

Transition to lower altitude, steep-slope communities. It has slightly steeper slopes than the typical cliff summit community and is often moderately exposed to the influence of salt spray. There are also higher soil conductivity levels, which can be attributed to higher levels of wind-borne salt effects (see below). Pterocelastrus tricuspidatus and Lampranthus sociorum are occasionally present. This community is further marked by the absence of: Tetraria cuspidata, Viscum capense and Syncarpha paniculata.

\section{Pterocelastrus tricuspidatus-Ruschia tenella Coastal Scrub Community}

The woody component of this community reflects the species composition of the coastal scrub in the deeply incised valleys along this coastline and there is possibly a floristic gradient from this community into thicket on other steep slopes. Diagnostic species: Pterocelastrus tricuspidatus as well as infrequent occurrence of Sideroxylon inerme, Delosperna edwardsiae and Cineraria britteniae. 


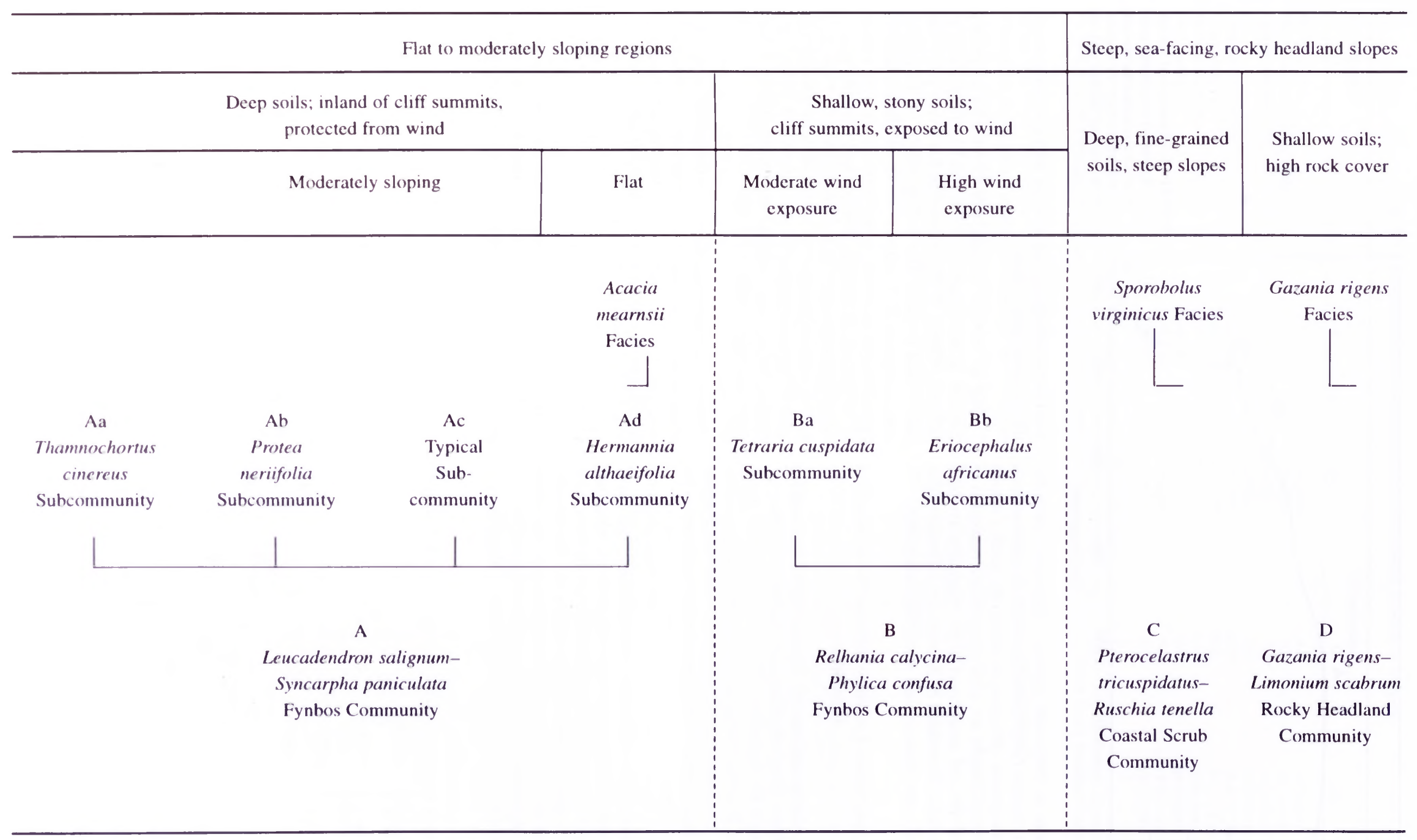




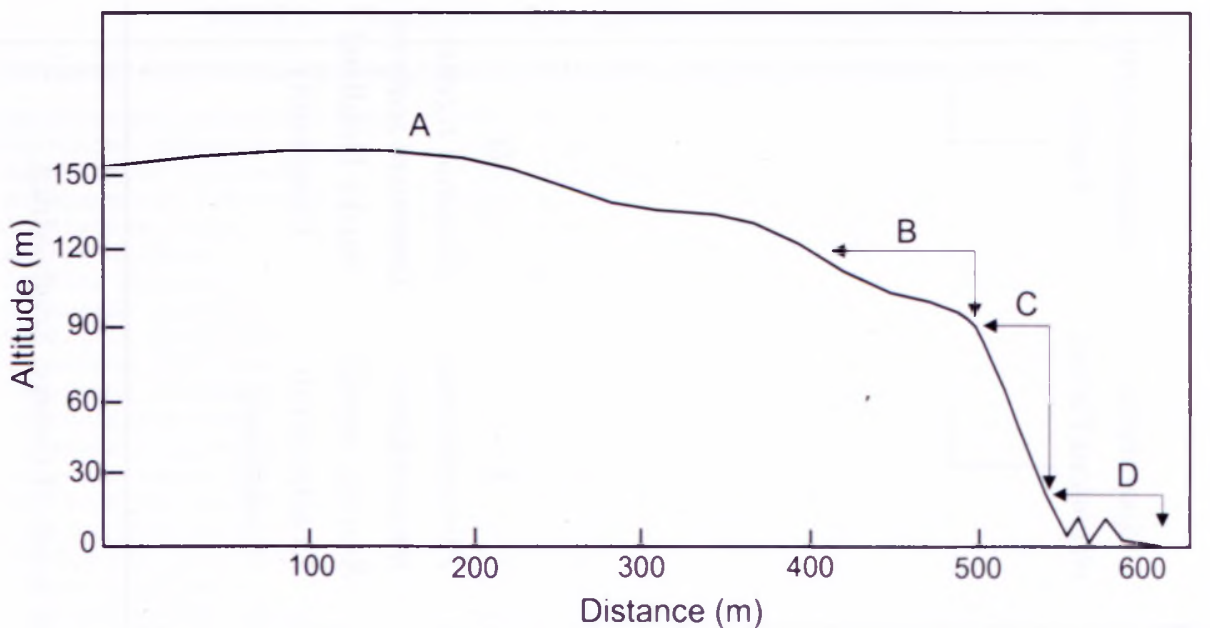

FIGURE 3.-Generalised profile diagram of coastal area south of George indicating the spatial relationship of communities to one another and the sea

Common or dominant species: Passerina vulgaris, Phylica confusa, Lampranthus sociorum, Agathosma ovata and Eriocephalus africanus, as well as the shrub Colpoon compressum. Shrubs are wind-cropped to a maximum of $1 \mathrm{~m}$, and the total aerial cover of the vegetation averages $60 \%$. A facies, dominated by Sporobolus virginicus (Table 2 , rel. 62), was distinguished within this community.

\section{Gazania rigens-Limonium scabrum Rocky Headland Community}

Salt-tolerant asteraceous Gazania rigens var. uniflora and a taxon from the Limonium scabrum complex accompanied by mesembs such as Drosanthemum marinum and Ruschia tenella, as well as other leaf succulents such as Crassula sp. and Sarcocaulon natalense, form an assemblage typical of the exposed rocky headlands in the southern Cape.

Community $\mathrm{C}$ and the rocky headland 'herbland' Community $\mathrm{D}$ have many species in common, which can be ascribed to a so-called neighbourhood effect (or mass effect; Shmida \& Wilson 1985). Naturally, the exposed Community D is virtually lacking (except of Sarcocaulon natalense) in its 'own' diagnostic species because of the environmental stress in the form of deposition of wind-borne salt that poses a major selective pressure on the potential species pool.

Due to the low altitude this community is greatly exposed to the influence of the wind and especially to salt spray (Figure 3 ). The vegetation has a very low cover and is wind-cropped. The average height of the vegetation is between 0.13 and $0.33 \mathrm{~m}$. Of all the community types, this one is lowest in species richness with a mean of 10 species on average. Shallow soil covering granite rocks is characteristic, and is often less than $5 \mathrm{~cm}$ deep and very stony. Surface boulders are often present and modify the microhabitat to some degree. A facies with Gazania rigens var. uniflora was distinguished within this community (Table 2, rel. 68).

This species composition corresponds with the description of similar rocky headland communities described for other parts of the coastline at Plettenberg Bay (Hellström 1990) and Port Alfred (Lubke 1983).

\section{Gradient analysis}

The ordination of the fynbos communities (Figure 4) revealed a horseshoe structure allowing the direct recognition of a coenocline spanning two fynbos communities

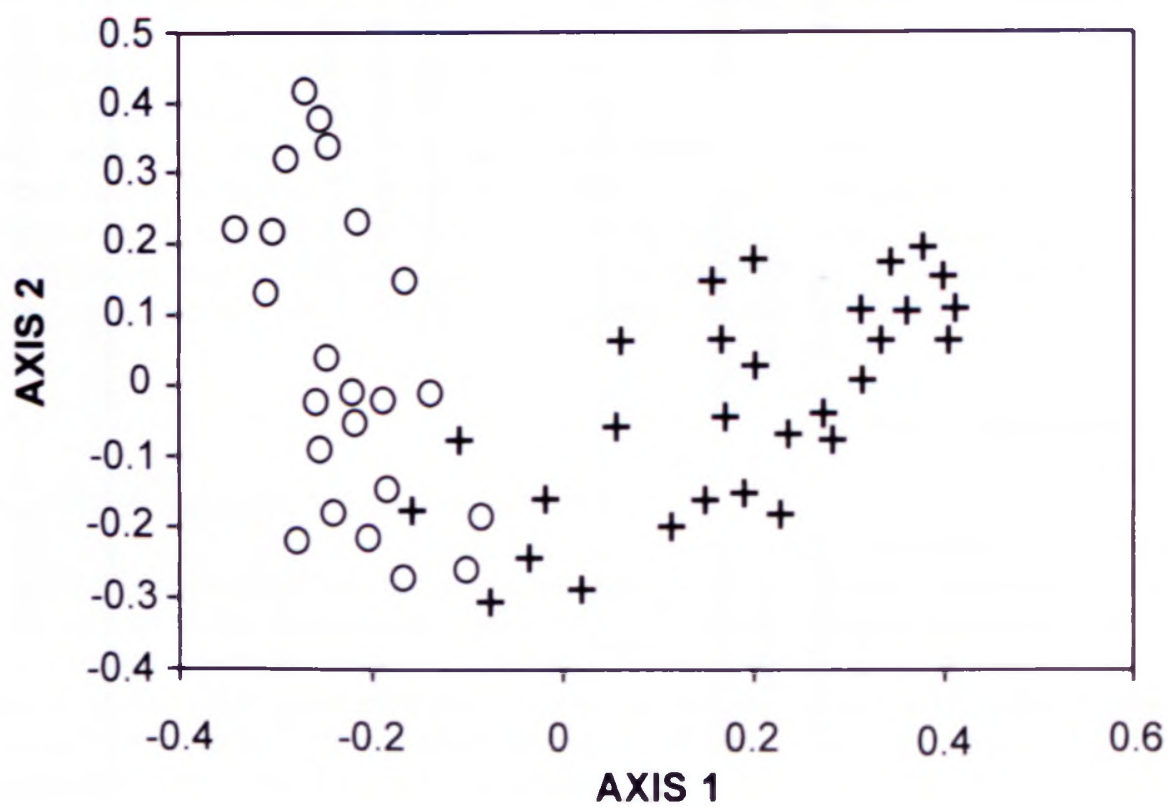

AXIS 1
FIGURE 4-Ordination of fynbos vegetation using Principal Coordinates Analysis + , relevés of the Relhania calycina-Phylica confusa Fynhos Community; ), relevés of the leucadendron salisnumSyncarpha paniculata Fynhos Community 
TABLE 3.--Soil properties for communities (mean with standard deviation in brackets)

\begin{tabular}{|c|c|c|c|c|}
\hline \multirow{2}{*}{ Soil parameter } & \multicolumn{4}{|c|}{ Community } \\
\hline & A & B & $\mathrm{C}$ & $\mathrm{D}$ \\
\hline Moisture (\%) & $2.6(2.3)$ & $3.2(2.8)$ & 4.2 & $1.9(1.5)$ \\
\hline Water-holding capacity $(\mathrm{ml} / \mathrm{g})$ & $0.7(0.1)$ & $0.9(0.2)$ & 0.7 & $0.5(0.1)$ \\
\hline Organic material $(\%)$ & $7.0(3.1)$ & $12.3(5.0)$ & 7.8 & $4.4(1.1)$ \\
\hline $\mathrm{pH}$ & $6.1(0.2)$ & $5.9(0.2)$ & 6.3 & $6.4(0.1)$ \\
\hline Conductivity ( $\mathrm{mS} / \mathrm{m}$ ) & $18.3(9.2)$ & $29.5(18.9)$ & 40.2 & $26.8(10.5)$ \\
\hline Coarse sand $(\%)$ & $53.6(10.9)$ & $64.2(6.5)$ & 56.9 & $59.5(15.9)$ \\
\hline Medium sand (\%) & $11.2(3.7)$ & $11.0(2.2)$ & 14.5 & $13.9(6.4)$ \\
\hline Fine sand $(\%)$ & $21.4(6.8)$ & $13.8(3.2)$ & 16.0 & $14.2(6.4)$ \\
\hline Silt $(\%)$ & $11.9(1.6)$ & $10.1(2.7)$ & 6.6 & $8.2(1.1)$ \\
\hline Clay $(\%)$ & $\mathrm{I} .8(0.8)$ & $0.9(0.5)$ & 6.0 & $4.3(2.0)$ \\
\hline Number of samples & 5 & 12 & 1 & 2 \\
\hline
\end{tabular}

A, Leacadendron salignum-Syncarpha paniculata Fynbos Community; B. Relhania calycina-Phylica confusa Fynbos Community; C, Ptericelastrus tricuspidatus-Ruschia tenella Coastal Scrub Community; D, Gazania rigens-Limonium scabrum Rocky Headland Community

along Axis 1 of the scatter diagram. There was a clear separation along this coenocline between the Relhania calycina-Phylica confusa Fynbos Community and the Leucadendron salignum-Tetraria cuspidata Fynbos Community. This pattern is interpreted in terms of exposure to wind and salt spray as reflected in topographical features and soil properties.

A classification scheme accompanied by associated environmental relationships (Figure 2) suggests that the Leucadendron salignum-Tetraria cuspidata Fynbos Community occurs on deep soils inland of the cliff summits where the vegetation is protected from wind and salt spray. The Relhania calycina-Passerina vulgaris Fynbos Community occurs on shallow, stony soils on the cliff summits, where there is a higher exposure to wind and salt spray.

Physical soil properties varied from community to community (Table 3 ). Cliff summits had the highest proportion of coarse sand, slopes above the cliff summits had the highest proportion of silt, and steep tallus slopes and rocky headland slopes had the highest proportions of medium sand, fine sand and clay. This is a trend in decreasing sand particle size away from the cliff summit (below and above) and larger proportion of clay to silt below the cliff summits (steep tallus slopes and rocky headland slopes).

Soil conductivity levels showed a decreasing trend as exposure to wind from the sea decreased. High levels were recorded on the steep tallus slopes, the cliff summits and the rocky headland slopes. The two cliff summit communities showed a difference in conductivity levels with the Eriocephalus africanus Subcommunity having higher conductivity measures than the Tetraria cuspidata Subcommunity. These higher conductivity levels were attributed to higher salinity levels from wind-borne salt spray effects.

Fire appeared to play an important role in the nature of the communities especially in the Leucadendron salignum-Syncarpha paniculata Fynbos Community where the subcommunities $\mathrm{A} a$ and $\mathrm{Ab}$ could be separated from the subcommunities $\mathrm{Ac}$ and Ad based on evidence of recent burning. We suggest that the subcommunities are distributed along a fire-induced succession gradient, but with site-specific effects also coming into play.

\section{ACKNOWLEDGEMENTS}

We are indebted to Gavin Hellström, previously of Cape Nature Conservation, George, for initiating this study and for the provision of maps, ortho-photographs and aerial photographs.

\section{REFERENCES}

ACOCKS, J.P.H. 1988. Veld types of South Africa, edn 3. Memoirs of the Botanical Survey of South Africa No. 57.

AVIS, A.M. \& LUBKE, R.A. 1985. The effect of wind-borne sand and salt spray on the growth of Scirpus nodosus in a mobile dune system. South African Journal of Botany 51 : 100-110

BRAUN-BLANQUET. J. 1964. Pflanzensoziologie. Grundzuege der Vegesationskunde, edn 3. Springer-Verlag, Wien.

BOUCHER, C. 1977. A provisional checklist of flowering plants and ferns in the Cape Hangklip area. Joumal of South African Botuny 43: 57-150

COWLING. R.M. 1984. A syntaxonomic and synecological study in the Humansdorp region of the Fynbos Biome. Bothalia 15: 175-227

COWLING. R.M \& HOLMES. P.M. 1992. Flora and vegetation. In R.M. Cowling. The ecology of finbos: nutrients, fire and diversity: 23-61. Oxford University Press, Cape Town.

DEACON. H.J., JURY. M.R. \& ELLIS. F. 1992. Selective regime and time. In R.M. Cowling. The ecology of fynbos: nutrients, fire and diversin: 6-22. Oxford University Press, Cape Town.

HELLSTRÖM, G. 1990. A phytosociological classification, with management proposals, of the Robbery Nature Reserve, Plettenberg Bay. B.Sc. (Hons) thesis, Rhodes University, Grahamstown.

HILL. M.O. 1979. TWINSPAN-a FORTRAN program for arranging multrvariate dasa in an ordered two-nay table by classification of the individuals and attributes. Ecology \& Systematics, Cornell University, Ithaca. N.Y

HOARE. D B. 1994. Assessing successional effects on plant diversin in the Goukamma Nature Reserve. southern Cape. B.Sc. (Hons) thesis, Rhodes University. Grahamstown.

JARMAN ML 1986. Conservasion priorities in lowland regions of the Fymbos Biome. South African National Scientific Programmes Report No. 87. CSIR. Pretoria.

LOW. A.B \& REBELO. A.G. (eds). 1996. Vegetation of South Africa, Lesotho and Swaziland. Companion to the vegetation map of Soush Africa, Lesotho and Swaziland. Department of Environmental Affairs and Tourism. Pretoria.

LUBKE. R.A 1983. A survey of the coastal vegetation near Port Alfred. Eastem Cape. Bothalia 14: 725-738.

PODANI. J 1993, SYN-TAX-pc. Computer programs for multivariate data analysis in ecology and systematics. Version 5.0. User's Guide Scientia Publishing. Budapest.

PODANI. J 1994 Mulnivariate analysis in ecology and systematics. SPB Academic Publishing. The Hague

RLTHERFORD, M.C \& WESTFALL. R.H. 1994. Biomes of southem Africa an objective categorization, edn 2. Memoirs of the Bofanical Survey of South Africa No. 63 
SOUTH AFRICAN COMMITTEE FOR STRATIGRAPHY (SACS) 1980. Stratigraphy of South Africa. Part 1. Lithostratigraphy of the Republic of South Africa, South West Africa/Namibia, and the Republics of Bophuthatswana, Transkei and Venda. Geological Survey of South Africa Handbook No. 8. Government Printer, Pretoria.

SCHULZE, R.E. \& MCGEE, O.S. 1978. Climatic indices and classifications in relation to the biography of southem Africa. In M.J.A. Werger, Biogeography and ecology of southern Africa. Junk. The Hague.

SHMIDA, A \& WILSON, M.V. 1985. Biological determinants of species diversity. Journal of Biogeography 12: 1-20.

TAYLOR, H.C. 1985. An analysis of the flowering plants and ferns of the Cape of Good Hope Nature Reserve. South African Journal of Botany $51: 1-13$.

TAYLOR, H.C. \& BOUCHER, C. 1993. Dry coastal ecosystems of the South African south coast. In E. Van der Maarel, Ecosystems of the World 2B. Dry coastal ecosystems: Africa, America, Asia and Oceania. Elsevier, Amsterdam.
UNITED STATES DEPARTMENT OF AGRICULTURE (USDA) 1972. Soil survey laboratory methods and procedures for collecting soil samples. Soil Survey Report 1. US Government Printing Office, Washington, DC.

VAN DER MERWE, C.V. 1979. Plantekologiese aspekte en bestuursprobleme van die Goukamma-natuurreservaat. M.Sc. thesis, University of Pretoria.

WEATHER BUREAU 1994. Monthly weather report for the months January to December 1994. Weather Bureau, Pretoria.

WERGER, M.J.A. 1974. On concepts and techniques applied in the Zürich-Montpellier method of vegetation survey. Bothalia 11 : 309-323.

WESTHOFF, V. \& VAN DER MAAREL, E. 1973. The Braun-Blanquet approach. In R.H. Whittaker, Ordination and classification of plant communities. Junk. The Hague.

WORLD WIDE FUND FOR NATURE (WWF) 1999. Soruthernmost point of Africa: a gift to the earth. Africa-Environment and Wildlife Suppl. to 7,3: 9 . 